\title{
シロアリ食害材の強度特性と密度および超音波伝搬速度の関係
}

\author{
森拓 郎* 香 束 章 博** \\ 䇥 瀬 佳 $2^{* * *}$ 小松 幸 平****

\section{Relationships between Strength Properties and Density or Ultrasonic Velocity of Timber Attacked by Termite}

by

\author{
Takuro Mori ${ }^{*}$, Akihiro Kousoku ${ }^{* *}$, Yoshiyuki YanaSE ${ }^{* * *}$ and Kohei Komatsu ${ }^{* * * *}$
}

To evaluate a decrease in strength of wooden members and wood-based materials attacked by termites or wooddestroying fungi is important for long-term maintaining of wooden constructions. The relationships between strength and degree of biodeterioration of wooden members and wood-based materials were not evaluated properly, though there were few techniques for evaluating the degree of biodeterioration in wooden constructions using screwdriver, palpation or other apparatus. In this study, the strengths of three species of wood attacked by termites were evaluated using bending test and compression test of perpendicular to the grain, and the relationships between the strength and the density or the velocity of ultrasonic in the attacked wood were also investigated. As the results, European spruce specimens had large damage comparison with other species. Thus the density of attacked wood was positively correlated with the bending strength and young's modulus. The velocity of ultrasonic in attacked wood was loosely correlated with the bending strength and young's modulus. In the case of picking up the European spruce material, between the velocity of ultrasonic and bending strength or young's modulus showed good correlation. On the other hand, it was not found that the density and the velocity of ultrasonic were positively correlated with the compression strength and young's modulus.

Key words : Termite, Bending strength, Compression strength, Ultrasonic velocity, Density, Biodeterioration

\section{1 緒訔}

現在，住宅の長期使用を目指して，国土交通省が施 行した「長期優良住宅の普及の促進に関する法律」など を中心として様々な取り組みが進められている。この施 策を進めるに当たり木造住宅の長寿命化においては，木 質材料の安定的な長期使用が可能であることが重要な 要因となる．この場合，シロアリや木材腐朽菌による生 物劣化を受けた木材および木質材料の強度低下を正確 に評価することが必要となる。しかし，木材扎よび木質 材料については，「木造住宅の耐震診断と補強方法」, 「実務者のための住宅の腐朽・虫害の診断マニュアル」, および「木造住宅の耐久設計と維持管理・劣化診断」5) によって，その性能評価が非破壊検査と併せていくつか 紹介されているのみである。 また，その評価方法は，マ イナスドライバーの穿孔や触診，その他の機器を用いた ものなどが提案されているが, 決して工学的な見解が示 されているわけではなく，また正確な評価が可能である とは言い難い.

そのため，木造住宅を長寿命化するにあたって生物
劣化を受けた木材および木質材料の残存耐力を評価し， 木材や接合部に打ける補強方法や取り替えの目安など を検討できるようにすることが重要となる，この生物劣 化に打いて，腐朽とシロアリによる食害は連動している こともあるが，耐力低下の要因としては主にセルロース の分解と空洞化という異なった損傷であると考えられ る.そのため，腐朽とシロアリ食害を個別に捉えること が重要であると考え，シロアリによる食害とその食害材 に打ける残存耐力について注目すると，野口らの研究 6) や大村らの研究 7) などが見られるが，十分なデータが あるとは言い難く，またそのデータの蓄積は少ない. 地 震時になされた住宅の被害調査などではいくつかの報 告があり, ${ }^{8), 9)}$ それらは地震で倒壊や半壊など大きな被害 を受けた住宅の多くがシロアリや腐朽による生物劣化 を受けていたと報告している。これらのことより，シロ アリ食害による木材および木質材料の強度低下を評価 することは，地震などの被害や建物の長期性能を保証す るためには重要であると考えられる.

そこで本研究では，土台や柱に使われているオウシュ

$\dagger$ 原稿受理 平成 21 年 8 月 10 日 Received Aug. 10, 2009 @ 2010 The Society of Materials Science, Japan

* 正 会 員 京都大学生存圈研究所 ₹611-0011 宇治市五ヶ庄, Res. Inst. for Sustainable Humanosphere, Kyoto Univ., Gokasho, Uji, 611-0011

** 住友林業(楀)木材建材事業本部 干100-8270 東京都千代田区大手町, Sumitomo Forestry Co. Ltd., Timber and Building Materials Business Headquarters, Chiyoda-ku, Tokyo, 100-8270

*** 正 会 員 京都大学大学院農学研究科 =606-8502 京都市左京区北白川追分町, Graduate School of Agri., Kyoto Univ., Sakyo-ku, Kyoto, 606-8502

**** 京都大学生存圈研究所 =611-0011 宇治市五ヶ庄, Res. Inst. for Sustainable Humanosphere, Kyoto Univ., Gokasho, Uji, 611-0011 
ウトウヒ（俗称：ホワイトウッド)，スギ，ヒバをシロ アリに食害させ，その材料の曲げおよび全面横圧縮実験 によって残存耐力を評価するとともに，食害材の密度扔 よび超音波伝搬速度と材料強度の関係について検討 した.

\section{$2 \cdot 1$ 試験体}

\section{2 試 験 概 要}

試験体は, ヒバ (Thujopsis dolabrata), スギ (Cryptomeria japonica)，オウシュウトウヒ (Abies pectinata) の 3 樹 種で，ヒバは心去り，スギは心持ち，ホワイトウッドは E95-F270の異等級対象構成集成材であり，どの試験体 に扎いても辺材を含んでいた。 また，試験体の含水率 (ケット科学研究所製 HM-520 を用いて表面より計測) の平均值は，試験地設置前でヒバが $17.7 \%$ ，スギが $9.1 \%$, オウシュウトウヒが $11.0 \%$ であった. Fig. 1 に示すよう に 3 樹種をそれぞれ $105 \times 105 \times 1000 \mathrm{~mm}$ にカットした 後，木口からの食害を防ぐために醀酸ビニル接着剤を用 いてシーリングした。試験体は試験地である和歌山県 $\mathrm{M}$ 町にて，事前の餌杭による調査によってイエシロア リ (Coptotermes formosanus) の生息が認められた箇所 に設置し，食害を受けさせた。試験体の設置方法は，プ ラスチックス製の土壁などを練る際に用いる容器で蓋 をすることにより，シロアリが好むような出来る限り無 風で暗い環境を整えた（Fig. 2)，その容器内の温度と湿 度の状態の一部（2007 年 5 月 28 日より 11 月 26 日）を Fig. 3 に示す。 また，試験実施前の計測として，試験体 の質量，縦振動による動的ヤング係数打よび超音波伝搬 速度を測定した. 2007 年 4 月下旬に試験体を設置した後, 毎月 1 回程度，試験体へのシロアリ食害状況の経過観察 を行い，その都度食害が認められた試験体を用いて試験 を行った。

\section{$2 \cdot 2$ 曲げ試験}

曲げ試験は，生存圈研究所所有の Instron 製材料試験 機を用いて加力速度 $2 \mathrm{~mm} / \mathrm{min}$ で中央載荷の 3 点曲げと し，スパン $800 \mathrm{~mm}$ で実施した（Fig. 4)。試験体は，試 験地設置時の含水率に近づくまで室内環境下で風乾し， $50 \times 50 \times 1000 \mathrm{~mm}$ の寸法に 4 分割した。曲げ試験時の含 水率の平均值はヒバが $13.4 \%$ ，スギが $10.6 \%$ ，オウシュ ウトウヒが $11.0 \%$ であった。 また，コントロール試験と して食害試験に供しなかった健全材についても各樹種 4 体ずつ実施した。測定項目は，見かけの曲げヤング係数 を得るための中央たわみと，曲げ強度を得るための荷重 とし，データロガーを用いて連続的に計測した。

\section{$2 \cdot 3$ 全面横圧縮試験}

全面横圧縮試験は，曲げ試験と同様の試験機を用い て加圧板を固定して $0.5 \mathrm{~mm} / \mathrm{min}$ で実施した（Fig. 5). 試験体（約 $50 \times 50 \times 50 \mathrm{~mm} ）$ は，曲げ破壊に至らしめた 材料より，破壊の影響がほとんど見られないと判断した 部分から 1 つないし 2 つ切り出した。 ヒバとスギの試験 体には追い柾のような試験体も含まれていた。本試験に おける測定項目は，加圧盤間の変位と荷重であり，デー タロガーを用いて連続的に計測した。 なお，全面横圧縮

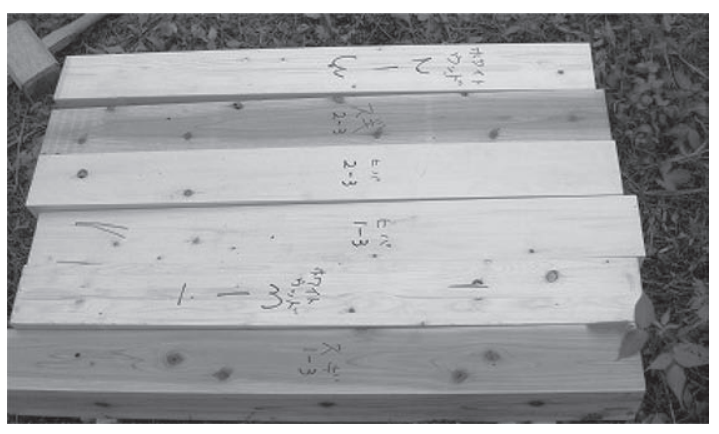

Fig. 1 Set-up of specimens on the site.
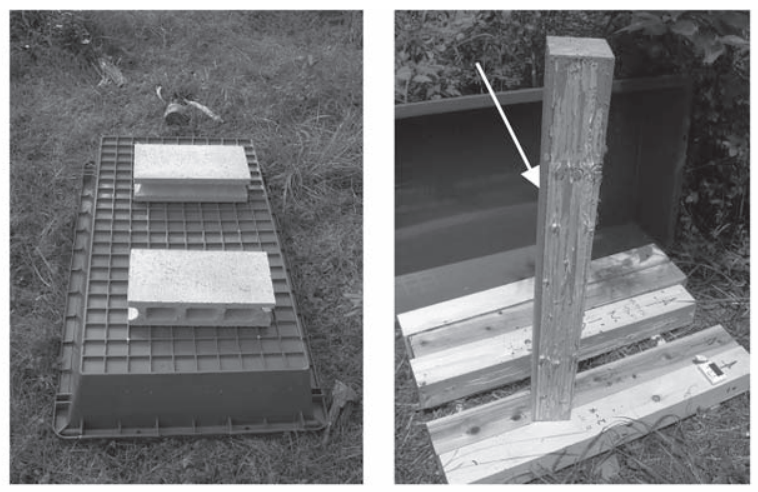

Fig. 2 Plastics container for covering specimens and specimens attacked by termite.

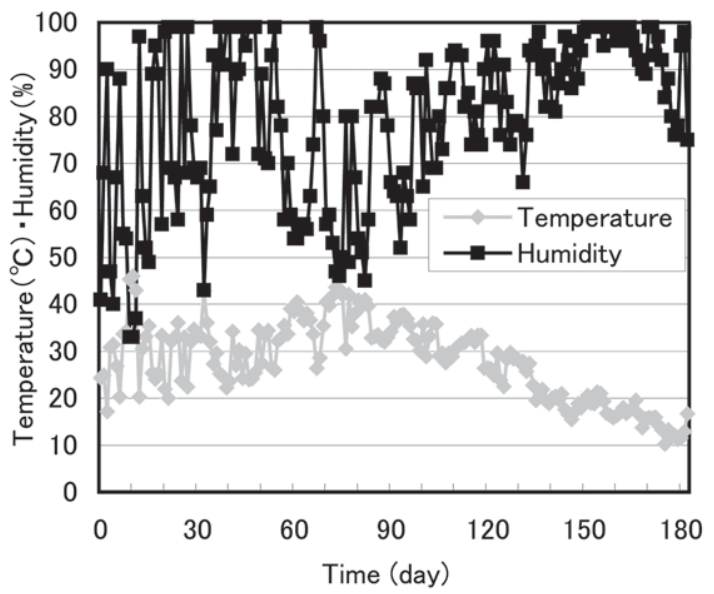

Fig. 3 The ambient of temperature and humidity of the specimens.

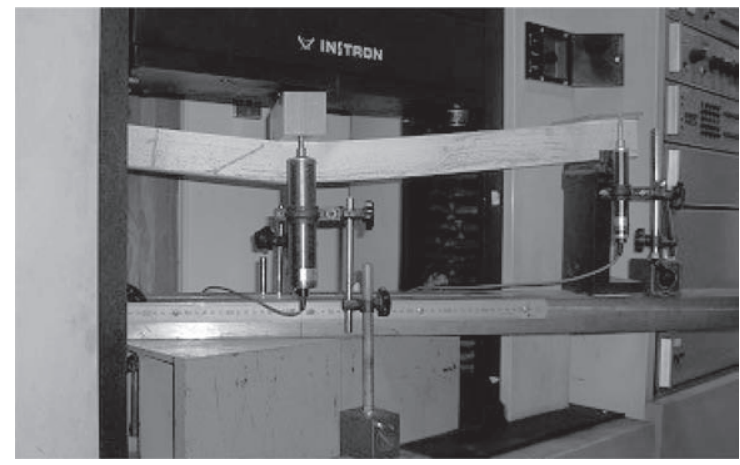

Fig. 4 Set-up of specimen for bending test. 
試験における降伏荷重は，初期剛性を $1 \mathrm{~mm}$ オフセット させた直線と実験值との交点とした。

\section{3 試験結果と考察}

\section{$3 \cdot 1$ シロアリ食害状況}

試験体の食害状況については，目視で明らかなほど 樹種間でその程度が異なり，オウシュウトウヒ>スギ> ヒバの順であった．これは，心材部の比率の違いもある と考えられるが，木材工業ハンドブック 10) に示されて いる木材の心材部による生物劣化の耐久性と同様の結 果であり，本試験での食害条件が特異な状況ではなかっ たと考える. 特にオウシュウトウヒについては，最も激 しい食害が見られ，大きな断面欠損を起こしていること が看取された。な拉，本試験に用いたオウシュウトウヒ が集成材であったために，その接着層で一度食害が止ま り，その後食害できる箇所が減るとともに接着層へも食 害が進行する傾向があることが見て取れた。その他の樹 種についてはあまり激しい食害は見られなかった。スギ では辺材部が主に食害され，ヒバについては特に食害の 程度が低く，耐蟻性が高いことが改めて確認された。

\section{$3 \cdot 2$ 曲げ試験}

曲げ試験により得られた強度性能の值と各非破壊測 定值との関係を Fig. 6〜 11 に示す. なお，ここで示す 密度は容積密度であり，曲げ試験体の質量を曲げ試験体 の外寸から求めた容積で除したものである，加えて，含 水率補正はしていない。また，破壊性状は，比較的食害 の少ない材については曲げ破壊を示したが，比較的食害 の大きな材については支点や加力点が圧壊して加力で きないものなども見られた。

Fig. 6，7より密度とヤング係数抢よび曲げ強度は, 健全材で一般的に言われているように，正の相関関係が あり，実際の建物内での測定を無視するとこれらの值 は，データベースの構築によって，劣化の程度を調べる ことができるようになると考えられる。ただし，実際に シロアリ食害を受けた場合，シロアリが運ぶ土や分泌物 のために密度が実食害量での評価よりも大きくなり，土 などの運び込みが少ないものでなければ，正確に判断す ることは難しいと考えられる．今後，これらの傾向を踏 まえた上での評価方法や測定方法が必要である.

また，一般的に被害度を調べるために用いられてい る密度の減少率とヤング係数抢よび曲げ強度の関係を Fig. 8，9 に示す．なお，元の密度は $105 \times 105 \times 1000 \mathrm{~mm}$ 時に計測した值を用い，含水率による補正は行っていな い.これらも同様に，密度減少率が高いほどヤング係数 および曲げ強度が低下する傾向を示した。しかし，減少 率 $10 \%$ 以下で值がばらつく理由は，木材自身のバラッ キが大きいためと考えられる，また，より精度良く食害 による損傷を評価するためには食害位置とヤング係数 および強度の関係などについても検討する必要がある と考えられる.

次に，Fig. 10，11 に超音波伝搬速度との関係を示す. ヤング係数拈よび曲げ強度とは，正の相関関係が見られ るものの，密度に比べてあまり高い相関ではなかった。

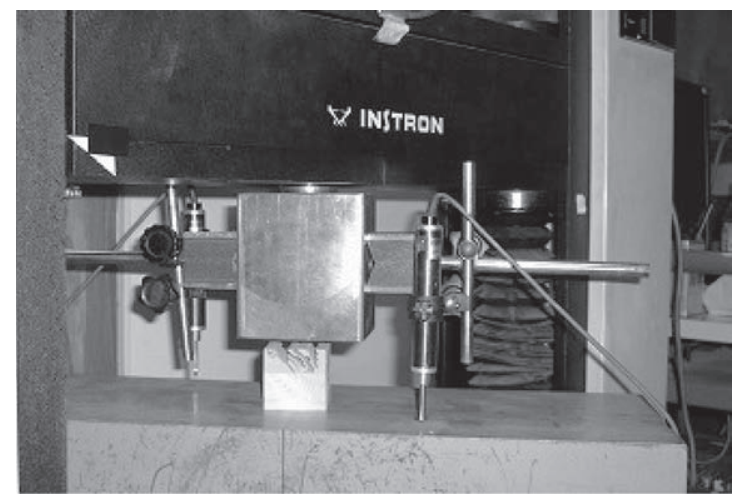

Fig. 5 Set-up of specimen for compression test.

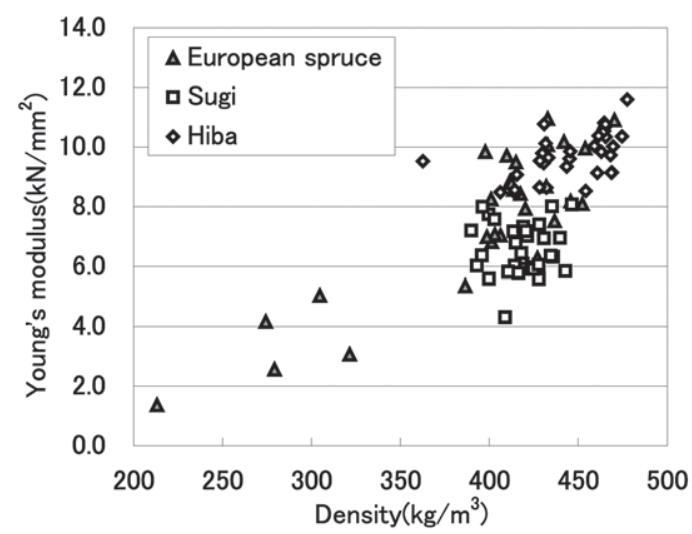

Fig. 6 Relationship between young's modulus and density.

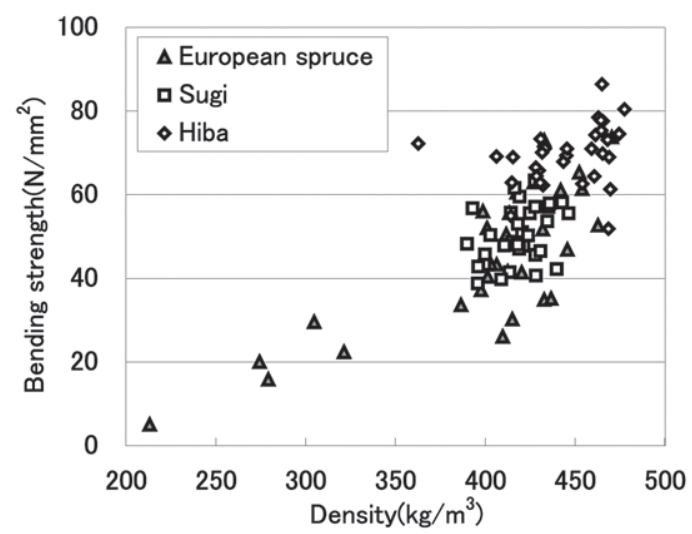

Fig. 7 Relationship between bending strength and density.

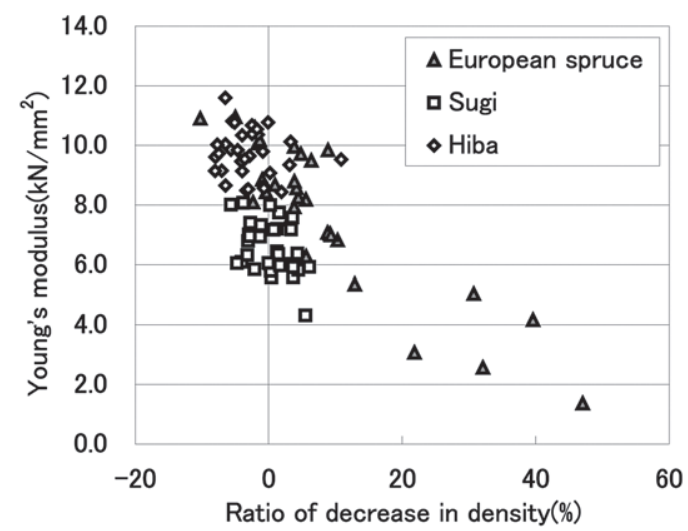

Fig. 8 Relationship between young's modulus and ratio of decrease in density. 
しかし，食害の比較的大きいオウシュウトウヒのみに注 目して近似直線を示すと，高い相関を示していることが わかる．このことから，食害の大きな材の実験を重ねる ことでこの評価がより精度良くなると考えられる.

\section{$3 \cdot 3$ 全面横圧縮試験}

全面横圧縮試験により得られた強度性能の值と各非 破壊測定值との関係を Fig. 12 〜 17 に示す. ここで示す 密度とは，前述と同様に計算した容積密度であり，圧縮

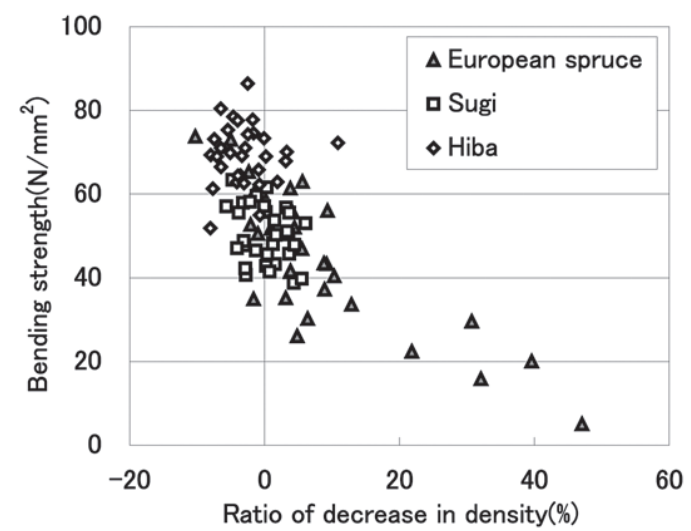

Fig. 9 Relationship between bending strength and ratio of decrease in density.

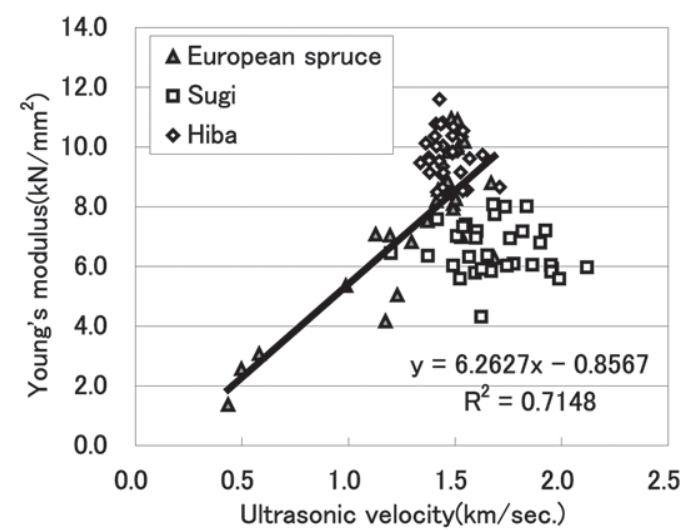

Fig. 10 Relationship between young's modulus and ultrasonic velocity, note: line shows the fitted curve of European spruce.

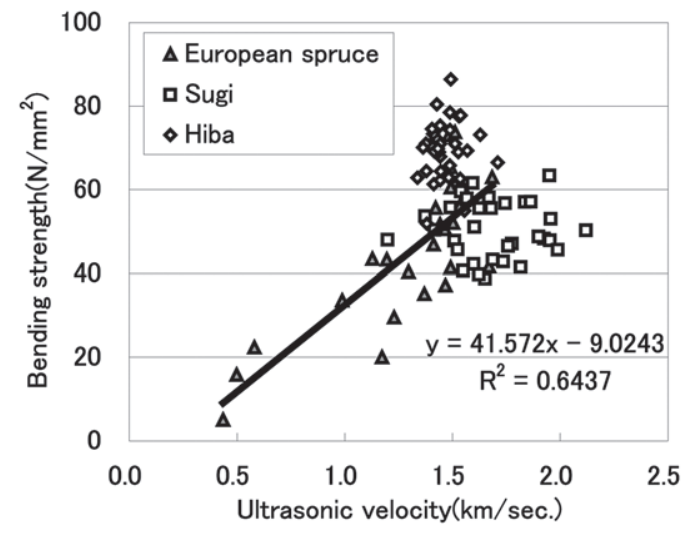

Fig. 11 Relationship between bending strength and ultrasonic velocity, note: line shows the fitted curve of European spruce.
試験体の外寸および質量より求めた。なお，含水率によ る補正は行っていない，また，破壊性状については，追 い柾の試験体では食害が年輪に沿って起こるために早 期に外縁部 (辺材部) がはがれるものなどが見られ，才 ウシュウトウヒでは試験体が左右に割れてしまうよう なものも見られたが，ほとんどの試験体は徐々に圧壊し ていく一般的なものであった.

Fig. 12，13より横圧縮ヤング係数打よび降伏強度と 密度の関係を示す．測定值にバラツキがあるが，密度 $350 \mathrm{~g} / \mathrm{m}^{3}$ 付近で，横圧縮ヤング係数扔よび降伏強度が 0 に近い值となりほとんど性能を保持できていないこと がわかる．特に食害の大きかったオウシュウトウヒにつ いては，集成材を用いていたために柾目に圧縮力を加え てしまう試験体が多くなり，早期に割れるなどして横圧 縮ヤング係数および降伏強度が比較的低いものが増え てしまった。 そのため，今後追加試験をするにあたって は，集成材でない部材を使って評価する方がよりわかり やすいと考える。また，曲げ試験と同様に，横圧縮ヤン グ係数扣よび降伏強度は密度と正の相関があることが 確認された。

また，Fig. 14，15 に密度の減少率と横圧縮ヤング係数 および降伏強度の関係を示す．なお，元の密度は $105 \times$ $105 \times 1000 \mathrm{~mm}$ 時に計測した值を用いた．横圧縮ヤング

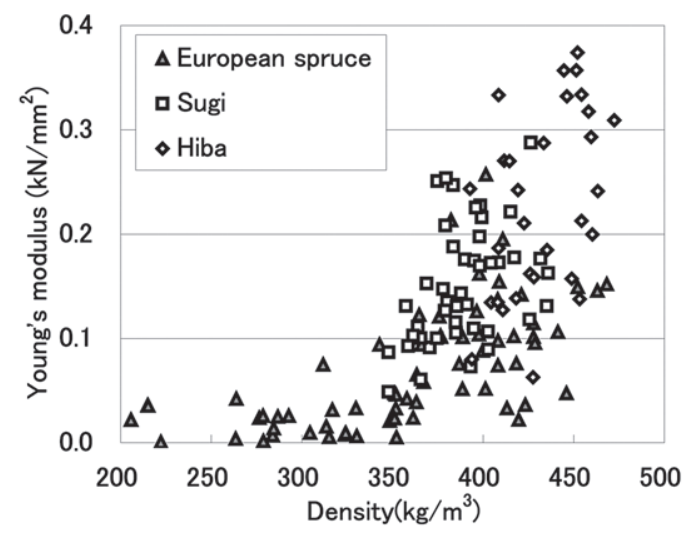

Fig. 12 Relationship between young's modulus of perpendicular to the grain and density.

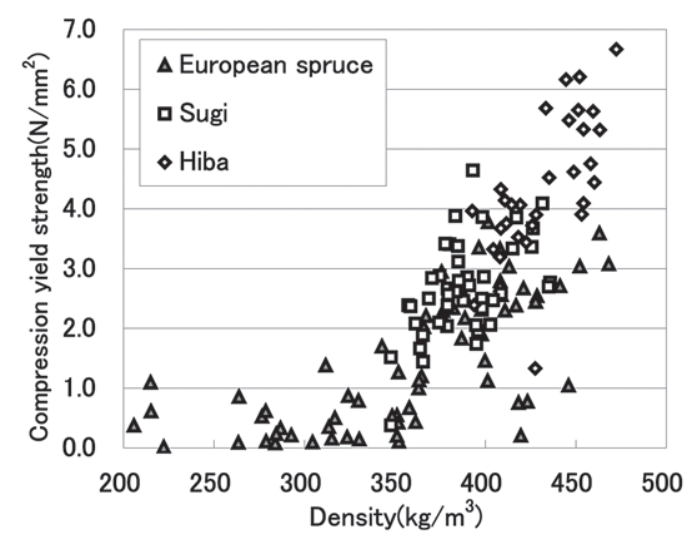

Fig. 13 Relationship between compression yield strength and density. 
係数および降伏強度は，わずかな密度の減少でも顕著に 低下することがわかった。

次に, Fig. 16，17 に横圧縮ヤング係数および降伏強 度と超音波伝搬速度の関係を示す。曲げ試験と同様に, 超音波伝搬速度のバラツキが大きく，正の関係は見られ るものの，あまり高い相関とはいえない。これは，試験 体寸法が小さいため，試験体の食害が少ない時，超音波 の伝搬時間があまりにも短いことが影響しているもの と考えられる。

また，今回の全面横圧縮試験時は，Fig. 18 に示すよ うに，試験体が圧縮されることによって，シロアリ食害 による空隙部分が徐々に減少することで初期の破壊が 起こっているが，その後，空隙が埋まると剛性や荷重が 上昇することがあった。そのため，より明確に残存耐力 を評価する試験方法についても検討する必要がある.

\section{4 結言}

本試験により，シロアリ食害を受けた木材の強度性 能を評価する上でいくつかの重要な知見が得られた。

食害を受けた木材に扔いても，健全材と同様に，密 度と強度扎よびヤング係数には正の高い相関が見られ た.この密度を把握する方法と強度およびヤング係数と の組み合わせで，シロアリ食害による生物劣化の程度を 評価できる可能性を得た。そのためには，密度のみで評

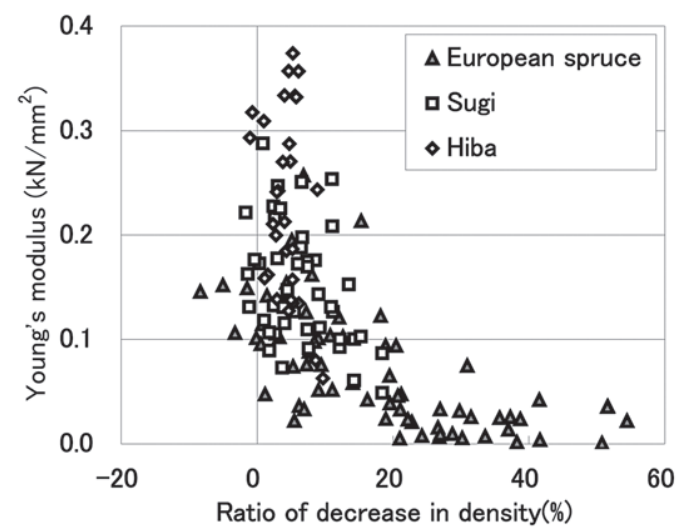

Fig. 14 Relationship between young's modulus of perpendicular to the grain and ratio of decrease in density.

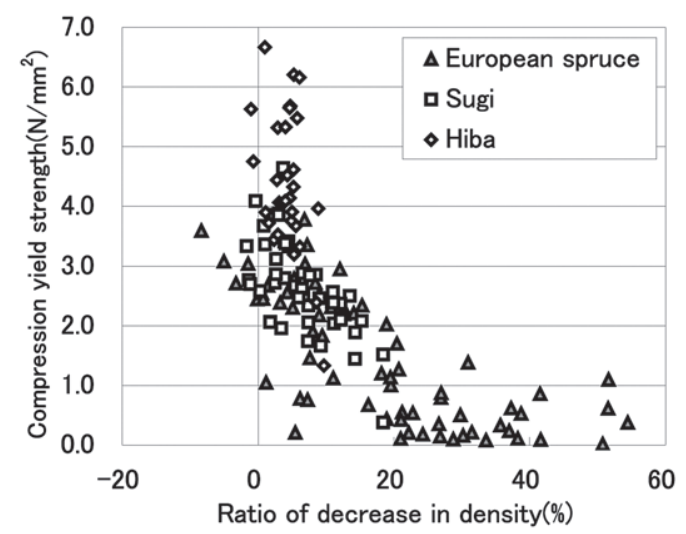

Fig. 15 Relationship between compression yield strength and ratio of decrease in density.
価できるのか，樹種による影響を考慮する必要性がある のかを確認する必要がある．また超音波伝搬速度におい ては，ヤング係数拈よび曲げ強度とは正の関係が見られ るものの，密度に比べて相関は高くなかった，圧縮試験 では，密度および超音波伝搬速度がわずかに低下した食 害の初期段階において，横圧縮ヤング係数および降伏強 度が著しく低下することが確認された。超音波伝搬速度 の計測によって，強度やヤング係数と正の相関を得るこ とはできた。この非破壊診断で食害の程度が大きなもの については評価できることはわかったが，より小さな食 害について評価を可能にする方法の検討が必要である.

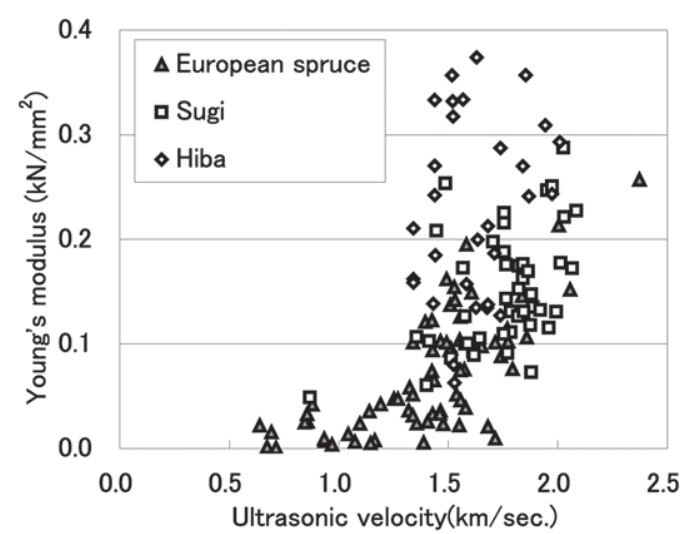

Fig. 16 Relationship between young's modulus of perpendicular to the grain and ultrasonic velocity.

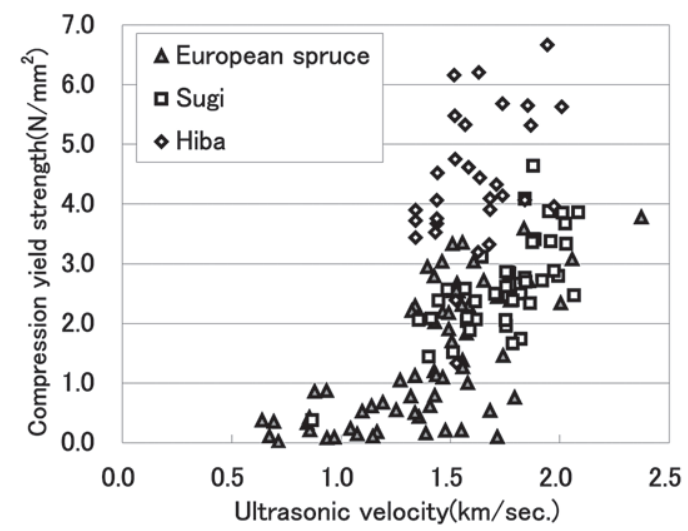

Fig. 17 Relationship between compression yield strength and ultrasonic velocity.
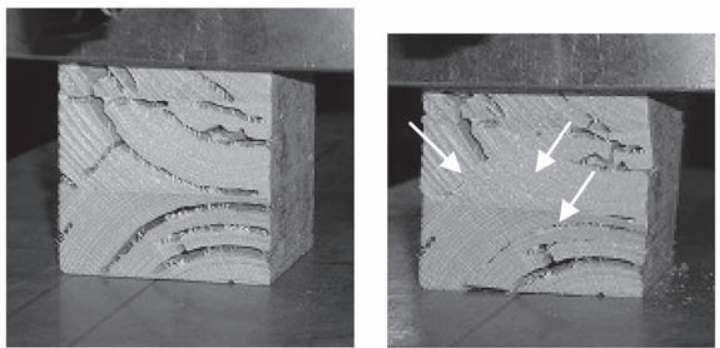

Fig. 18 A state of the deflection note: left is before the compression test, right shows the some of cavity were buried during the compression test. 
今後，超音波の伝搬に打ける波形の解析，穿孔抵抗 や打ち込み深さ試験などの診断方法についても同様の 検討を行い，統一的なデータを作成して行くことが重要 と考える。

本研究を行うにあたり，トステム建材産業財団（代 表者：森 拓郎), 科学研究費補助金（基盤研究 (B) 19380101 : 代表者：小松幸平), および京都大学生存圈 研究所の全国共同利用研究居住圈劣化生物飼育棟 （DOL）による補助を受けました。また，本研究を始め るにあたり, 京都大学大学院農学研究科藤井義久准教授 および藤原裕子氏，京都大学生存圈研究所吉村剛准教授 にアドバイスをいただきました。 また，京都大学生存圈 研究所小松研究室の学生諸氏に実験の補助を打願いし ました。ここに謝意を表します。

本論文の一部は文献 1)，2）にて発表しており，修正と 新たな考察を加えて加筆したものである。

\section{参 考 文 献}

1) T. Mori, A. Kousoku, Y. Yanase and K. Komatsu, "A Basic Study on Estimating of Surviving Strength of Timber Attacked by Termite", Proceedings of the $11^{\text {th }}$ Technical Meeting of Japan Timber Engineering Society, pp.62-65 (2007)

2 ) T. Mori, A. Kousoku, Y. Yanase and K. Komatsu, "A Basic Study on Estimating of Surviving Strength of Timber Attacked by Termite Part2", Proceedings of the $12^{\text {th }}$ Technical Meeting of Japan Timber Engineering Society, pp.21-24 (2008)

3 ) The Japanese Building Disaster Prevention Association, "Seismic diagnosis and reinforcement method for residential wooden house”, pp.125-126, pp.312-330 (2006)

4) Japan Wood Preserving Association, "Diagnosis manual of the fungi and the pest damage of residential house for strategist”, pp.98-110 (2004)

5) Japan Housing and Wood Technology Center, "The durability design and control of maintenance and deterioration diagnosis for residential wooden house", pp.105-129 (2002)

$6)$ M. Noguchi, T. Yoshimura and K. Miyazawa, "The compressive strength of the terminated timber”, Journal of Structural Engineering, Vol.54B, pp.171-176 (2008)

7 ) W. Ohmura, K. Yamamoto, H. Ido, H. Nagao, H. Kato, K. Momohara, H. Matsunaga, A. Miyatake and Y. Kodate, "Change in Durability of Glued Laminated Timber under Accelerated Decay Conditions and Compression Strength Perpendicular to the Grain after Decay”, Wood Industry, Vol.61, No.10 (2006)

$8)$ T. Doi, M. Miyano, Lu Heng Jian and H. Kitamoto, "Influence of Biological Degradation to the Wooden House damaged by Hyogo-ken Nanbu Earthquake”, Summaries of technical papers of annual meeting architectural institute of Japan on Kinki brunch, Structure, Vol.35, pp.221-224 (1995)

9) T. Mori, Y. Yanase, S. Murakami and A. Kousoku, "Earthquake and Biological Damages of Wooden Dwelling Houses subjected to Chuetsu-Oki Earthquake”, Termite Journal, Vol.149, pp.11-19 (2008)

10) Forestry and Forest Product Research Institute, "Handbook of wood industry -improved edition 4-", p.795 (2004) Maruzen 